\title{
Job stress, satisfaction, and mental health among general practitioners before and after introduction of new contract
}

\author{
Valerie J Sutherland, Cary L Cooper
}

\begin{abstract}
Objective-To compare measures of job stress, job satisfaction, and mental health among general practitioners before and after the introduction of the new contract in April 1990.
\end{abstract}

Design-Cross sectional postal questionnaire survey in July 1990. Comparison of results with those obtained in previous survey in November 1987.

Setting-General practice in United Kingdom.

Subjects -1500 general practitioners randomly selected from general medical services lists, 917 of whom $(61 \%)$ returned questionnaires usable for statistical analysis.

Main outcome measures-Aspects of job causing stress, job satisfaction (Warr, Cook, and Wall scale), and mental health (Crown-Crisp experiential index).

Results-Compared with 1987, in 1990 doctors experienced more stress from night calls (mean score 3.83 in $1990 v 3.45$ in 1987), emergencies during surgery hours $(3.72 v 3.48)$, and interruption of family life by telephone $(3.58 v 2.73 ; \mathbf{p}<0.001$ for all three variables). Scores for somatic anxiety and depression were higher in both men and women in 1990 (men: somatic anxiety 3.12 $v 2 \cdot 36$; depression $3.80 v 2.94$; women: somatic anxiety $3.56 v 2.65$; depression $4.02 v 3.37 ; \mathbf{p}<0.001)$. Job satisfaction had also decreased in $1990(5.23 v 4.26 ; p<0.001)$.

Conclusions-Doctors experienced more stress, less job satisfaction, and poorer mental health in 1990 than in 1987. These changes may have resulted from the introduction of the new contract.

\section{Introduction}

The job strain model proposed by Karasek classifies general practice as a profession with high demand and high decision latitude.' This means that the high demands of the job will not be experienced as especially stressful while there is also freedom of action and autonomy in decision making. If autonomy is removed the high demands on doctors' time, the heavy workload, and responsibility for others may become intolerable burdens. The high demand nature of general practice is well documented: heavy workload, constant time pressures, and the problems of practice administration result in lack of leisure and free time and may cause spillover problems in home and family life..$^{2-6}$

The introduction of the new contracts in April 1990, at the end of a period of considerable dispute and disagreement, ${ }^{7-9}$ was the most extensive of a series of recent changes in general practice. ${ }^{10}$ "For example, general practitioners are increasingly required to work and cooperate as part of a multidisciplinary team with other autonomous professionals. ${ }^{12}$ Efficient and effective team work takes time and effort, and doctors have had little formal training. Medicine has become more of a business venture and general practitioners are likely to be confronted with the strains of balancing needs and demands of these new roles. ${ }^{13}$ In addition, the profession no longer commands such high regard, respect, and prestige as in the past, and potential for gratification and satisfaction may thus have been eroded.

All change necessitates adaptation, whether it is a positive or negative experience. ${ }^{14}$ Adaptation or readjustment requires energy, but people's resources are not infinite and too many changes may lead to stress, resulting in a wide range of physiological, psychological, or behavioural symptoms. ${ }^{15}$ Previous research has documented mortality and morbidity in general practitioners and suggests that this group may be at considerable risk of illness and other stress related problems. $^{4}$

The circumstances surrounding the introduction of the new contract might be supposed to have increased doctors' stress. We conducted this cross sectional survey to compare measures of occupational stress, job satisfaction, and mental health, before and after the contract was introduced.

\section{Subjects and methods}

SAMPLE

We sent a questionnaire pack and prepaid return envelope to a random, national sample of 1500 genera practitioners in July and August 1990. The question naires were not anonymous, and those who did not reply within 4 weeks were reminded by telephone. Confidentiality of individual data was assured by the return of the questionnaires to University of Manchester Institute of Science and Technology: guarantees were given to protect the identity of the respondents and to encourage honesty in reporting.

The findings of this survey were compared with the results obtained from 1817 general practitioners during November $1987 .{ }^{+}$As well as being done at different times of the year the surveys differed in that the 1984 survey was anonymous; it is not known to what extent this may impact on the findings from the two studies.

\section{MEASURING INSTRUMENTS}

Mental health was measured with a shortened version of the Crown-Crisp experiential index..$^{16}$ Three of the most reliable subscales were used-namely, free floating anxiety (unease, worry without specific cause), depression (sadness of mood), and somatic anxiety (general fatigue or aches or pains). Each of the subscales is composed of eight items (scored 0,1 , or 2 ) giving a maximum subscale score of 16; a low score is indicative of good health. Reliability and validity data have been reported. ${ }^{16}$

Fob satisfaction - Ten items (identified as appropriate to the sample) from the Warr, Cook, and Wall job satisfaction scale $^{17}$ were used to measure job satisfaction. Each item is rated on a seven point scale (high score $=$ high satisfaction). Reliability and validity data for this measure are available. ${ }^{17}$ 
Demographic factors-Details were obtained about age, sex, partnership, and full or part time work.

fob stress questionnaire - The 31 stressor item bank developed from interviews conducted by Cooper et al was used to allow comparison of the findings in 1987 and 1990. Each item was rated on a five point rating scale $(1=$ no pressure, $5=$ high pressure $)$.

TABLE I-Age, sex, and partnerships of general practitioners responding to surveys before and after introduction of new contract in April 1990

\begin{tabular}{lcc}
\hline Variable & $\begin{array}{c}\text { No }(\%) \text { in August } 1990 \\
(\mathrm{n}=917)\end{array}$ & $\begin{array}{c}\text { No(\%) in November } \\
1987^{+}(\mathrm{n}=1817)\end{array}$ \\
\hline Sex: & & \\
$\mathrm{M}$ & $670(73 \cdot 1)$ & $1474(81 \cdot 1)$ \\
$\mathrm{F}$ & $243(26 \cdot 5)$ & $343(18 \cdot 9)$ \\
Not classified & $4(0 \cdot 4)$ & \\
Age (years): & & $509(28 \cdot 0)$ \\
$25-34$ & $269(29 \cdot 3)$ & $638(35 \cdot 1)$ \\
$35-44$ & $452(49 \cdot 3)$ & $367(20 \cdot 2)$ \\
$45-54$ & $115(12 \cdot 5)$ & $276(15 \cdot 2)$ \\
$55-64$ & $67(7 \cdot 3)$ & $27(1 \cdot 5)$ \\
$\geqslant 65$ & $8(0 \cdot 9)$ & \\
Not classified & $6(0 \cdot 7)$ & $1649(91)$ \\
Working in & & \\
partnership & $853(93)$ & \\
\hline
\end{tabular}

TABLE II - Mean (SE) score ratings for job stressors in November $1987^{+}$and August 1990. Each dimension is rated on scale of 1 to 5 (high score $=$ high pressure)

\begin{tabular}{|c|c|c|c|}
\hline Dimensions & $\begin{array}{l}\text { November } 1987^{+} \\
\quad(n=1817)\end{array}$ & $\begin{array}{l}\text { August } 1990 \\
(\mathrm{n}=917)\end{array}$ & $t$ Value \\
\hline Fear of assault during night visits & $1 \cdot 77(0 \cdot 02)$ & $1 \cdot 88(0.04)$ & $2 \cdot 4^{\star}$ \\
\hline Visiting in extremely adverse weather conditions & $2 \cdot 27(0 \cdot 03)$ & $2 \cdot 19(0 \cdot 04)$ & 1.69 \\
\hline Adverse publicity by media & $2.01(0.03)$ & $2 \cdot 46(0.04)$ & $9 \cdot 4^{\star \star \star}$ \\
\hline Increased demand by patients and relatives for & & & \\
\hline second opinion from hospital specialists & $2 \cdot 15(0 \cdot 02)$ & $2.65(0.03)$ & $12 \cdot 4 \star \star \star$ \\
\hline No appreciation of your work by patients & $1.81(0.02)$ & $2 \cdot 18(0 \cdot 03)$ & $9 \cdot 8^{\star \star \star}$ \\
\hline Worrying about patients' complaints & $2.47(0.03)$ & $2.64(0.04)$ & $3 \cdot 5 \star \star$ \\
\hline Finding a locum & $2.03(0.03)$ & $1.97(0.04)$ & $1 \cdot 27$ \\
\hline 24 hour responsibility for patients' lives & $2.39(0.03)$ & $2.94(0.04)$ & $11 \cdot 2^{\star \star \star}$ \\
\hline Taking several samples in a short time & $1.74(0.02)$ & $2 \cdot 12(0 \cdot 04)$ & $9 \cdot 8^{\star \star \star}$ \\
\hline $\begin{array}{l}\text { Unrealistically high expectations by others } \\
\text { of your role }\end{array}$ & $2 \cdot 41(0 \cdot 02)$ & $2 \cdot 80(0 \cdot 04)$ & $8 \cdot 8^{\star \star \star}$ \\
\hline $\begin{array}{l}\text { Coping with phone calls during night and early } \\
\text { morning }\end{array}$ & $3.32(0.03)$ & $3.58(0.04)$ & $5 \cdot 5 \star \star \star$ \\
\hline Night calls & $3.45(0.02)$ & $3.83(0.04)$ & $8 \cdot 4^{\star \star \star}$ \\
\hline Interruption of family life by telephone & $2 \cdot 73(0 \cdot 02)$ & $3.58(0.04)$ & $18 \cdot 4^{\star \star \star}$ \\
\hline Emergency calls during surgery hours & $3.48(0.02)$ & $3 \cdot 72(0 \cdot 04)$ & $5 \cdot 4^{\star \star \star}$ \\
\hline Home visits & $2 \cdot 20(0 \cdot 02)$ & $2 \cdot 35(0.03)$ & $4 \cdot 3^{\star \star}$ \\
\hline Dealing with problem patients & $3 \cdot 28(0.02)$ & $3.24(0.03)$ & $1 \cdot 02$ \\
\hline Remaining alert when on call & $2 \cdot 10(0 \cdot 02)$ & $2.67(0.04)$ & $12 \cdot 7 \star \star \star$ \\
\hline Hospital referrals and paperwork & $1.89(0.02)$ & $2.74(0.03)$ & $25 \cdot 3^{\star \star \star}$ \\
\hline Conducting surgery & $2.07(0.02)$ & $2.08(0.04)$ & $0 \cdot 31$ \\
\hline Practice administration & $2 \cdot 12(0 \cdot 02)$ & $2.69(0.03)$ & $14 \cdot 3^{\star \star \star}$ \\
\hline Arranging admissions & $2 \cdot 32(0.02)$ & $2.44(0.03)$ & $3 \cdot 0^{\star}$ \\
\hline Working environment (surgery set up) & $1.64(0.02)$ & $2.03(0.03)$ & $10 \cdot 3 \star \star \star$ \\
\hline Time pressure & $3 \cdot 11(0.02)$ & $3.52(0.04)$ & $9 \cdot 3^{\star \star \star}$ \\
\hline Demands of your job on family life & $2.76(0.02)$ & $3.50(0.04)$ & $16 \cdot 9 \star \star \star$ \\
\hline Dividing time between your spouse and patients & $2 \cdot 37(0.02)$ & $3 \cdot 22(0.04)$ & $18 \cdot 3^{\star \star \star}$ \\
\hline Demands of job on social life & $2 \cdot 40(0.02)$ & $3 \cdot 13(0.04)$ & $16 \cdot 7 \star \star \star$ \\
\hline $\begin{array}{l}\text { Lack of emotional support at home, especially } \\
\text { from spouse }\end{array}$ & $1.67(0.02)$ & $1.87(0.04)$ & $4 \cdot 6^{\star \star}$ \\
\hline $\begin{array}{l}\text { Daily contact with dying and chronically ill } \\
\text { patients }\end{array}$ & $2 \cdot 13(0 \cdot 02)$ & $2.07(0.03)$ & 1.58 \\
\hline Dealing with the terminally ill and their relatives & $2.15(0.02)$ & $2.20(0.05)$ & $1 \cdot 32$ \\
\hline Dealing with friends as patients & $2 \cdot 23(0.02)$ & $2.45(0.04)$ & $5 \cdot 0^{\star \star \star}$ \\
\hline Dealing with relatives as patients & $2 \cdot 17(0 \cdot 03)$ & $2 \cdot 38(0.04)$ & $4 \cdot 3^{\star \star \star}$ \\
\hline
\end{tabular}

${ }^{\star} \mathrm{p}<0.05,{ }^{\star \star} \mathrm{p}<0 \cdot 01,{ }^{\star \star \star} \mathrm{p}<0 \cdot 001$

\section{STATISTICS}

Unpaired Student's $t$ tests were used to compare the two samples and sex differences for each variable separately. The Bonferroni test of inequality was used to minimise the risk of type I errors. Although the data were skewed the $t$ test was valid because of the large sample size.

\section{Results}

Questionnaires were returned by 1002 of the 1500 general practitioners; 917 questionnaires $(61 \%)$ could be used for statistical analysis. Because the questionnaires were sent out during a peak holiday period some questionnaires were returned after the cut off date for analysis.

Table I shows that a higher percentage of respondents were women in the 1990 survey than in $1987(26.5 \%$ (243) and $18.9 \%$ (343) respectively). This probably reflects the increasing numbers of women entering the profession. However, only 27 doctors reported working part time and so the results were not distorted by large numbers of women working on a part time basis. A higher percentage of respondents were in the 35-44 age group in $1990(49 \cdot 3 \%(452))$ than in $1987(35.1 \%$ (638)). Only $20 \cdot 7 \%$ (190) were aged more than 45 compared with $36.9 \%$ (670) in 1987. Thus the respondents in the 1990 survey had a younger profile.

Table II shows the mean ratings for the 31 job stressor items and comparisons between August 1990 and November 1987. On 25 of the 31 items significantly higher levels of pressures were recorded during August 1990. Night calls (mean score $=3 \cdot 83$ ), emergencies during surgery hours $(3 \cdot 72)$, and interruption of family life with telephone calls (3.58) comprised the top three sources of stress in 1990. Since sex could mask important differences in stress the mean score ratings were examined separately. Female general practitioners reported more stress than males for visiting in adverse weather conditions, fear of assault during night visits, finding a locum, the working environment, lack of emotional support at home, and dealing with friends or relatives as patients $(\mathrm{p}<0.01)$. They were less stressed than male doctors by emergency calls during surgery hours $(\mathbf{p}<0 \cdot 01)$.

Table III shows the mean scores obtained for each subscale of the Crown-Crisp experiential index and indicates that mental health was significantly poorer in 1990 than in November 1987. Both male and female general practitioners were more anxious, more depressed, and had higher levels of somatic anxiety (although these scores were still below the population norms). Male general practitioners continued to exhibit a much higher level of free floating anxiety, than the normative population, as observed in 1987. Scores for the women doctors, although higher than in 1987, were now consistent with the norm. In 1987 male genera practitioners reported depression levels consistent

TABLE III-Scores on Crown-Crisp experiential index for general practitioners in 1987 and 1990 and normative population (high score $=$ poor mental health

\begin{tabular}{|c|c|c|c|c|c|c|c|c|}
\hline \multirow[b]{2}{*}{ Factors } & \multicolumn{2}{|c|}{ General practitioners $1987^{4}$} & \multicolumn{2}{|c|}{ General practitioners 1990} & \multirow[b]{2}{*}{$t$ Valuef } & \multicolumn{2}{|c|}{ Population's } & \multirow[b]{2}{*}{$t$ Value } \\
\hline & $\begin{array}{c}\text { No of } \\
\text { subjects }\end{array}$ & Mean (SE) score & $\begin{array}{l}\text { No of } \\
\text { subjects }\end{array}$ & Mean (SE) score & & $\begin{array}{c}\text { No of } \\
\text { subjects }\end{array}$ & Mean (SE) score & \\
\hline \multicolumn{9}{|c|}{ Free floating anxiety: } \\
\hline Men & 1439 & $3 \cdot 70(0 \cdot 08)$ & 664 & $4 \cdot 76(0 \cdot 13)$ & $7 \cdot 33^{\star \star \star}$ & 340 & $2 \cdot 80(0 \cdot 15)$ & $9 \cdot 34^{\star \star \star}$ \\
\hline Women & 335 & $4 \cdot 48(0 \cdot 18)$ & 241 & $5.90(0.23)$ & $3 \cdot 78^{\star \star \star}$ & 415 & $5 \cdot 40(0 \cdot 17)$ & 1.76 \\
\hline \multicolumn{9}{|c|}{ Somatic anxiety: } \\
\hline Men & 1439 & $2 \cdot 36(0 \cdot 06)$ & 666 & $3 \cdot 12(0 \cdot 10)$ & $6 \cdot 8^{\star \star \star}$ & 340 & $4 \cdot 30(0 \cdot 16)$ & $7 \cdot 00^{\star \star \star}$ \\
\hline Women & 335 & $2 \cdot 65(0 \cdot 12)$ & 237 & $3.56(0 \cdot 17)$ & $4 \cdot 67^{\star \star \star}$ & 415 & $5 \cdot 70(0 \cdot 16)$ & $8 \cdot 63^{\star \star \star}$ \\
\hline \multicolumn{9}{|l|}{ Depression: } \\
\hline Men & 1439 & $2.94(0.07)$ & 662 & $3 \cdot 80(0 \cdot 12)$ & $7 \cdot 12^{\star \star \star}$ & 340 & $3 \cdot 20(0 \cdot 12)$ & $3 \cdot 91^{\star \star}$ \\
\hline Women & 335 & $3 \cdot 37(0 \cdot 13)$ & 236 & $4 \cdot 02(0 \cdot 16)$ & $3 \cdot 04^{\star \star}$ & 415 & $4 \cdot 40(0 \cdot 12)$ & 1.87 \\
\hline
\end{tabular}

$\star \star p<0 \cdot 01, \star \star \star p<0.001$

tComparison of general practitioners' scores in 1987 and 1990

†Comparison of general practitioners' scores in 1990 with that of normative population 
with the normative population, but these were signifcantly higher in 1990. Although the levels of depression among the women had also significantly increased, their scores were still consistent with the norm.

Table IV shows the mean scores and $t$ test results for each of the 10 items used from the Warr, Cook, and Wall job satisfaction scale. The results indicate that doctors were less satisfied in 1990 than in 1987 with regard to the amount of responsibility given, variety in the job, physical conditions at work, amount of freedom to choose own methods of working, and recognition received for good work $(p<0 \cdot 001)$. They were more satisfied with opportunities to use abilities, rate of pay, and hours of working $(\mathrm{p}<0.001)$. However, this result should be interpreted with care because certain sex and age differences existed; analysis of variance showed that age $(F=5 \cdot 33, \mathrm{p}<0.001, \mathrm{df}=3$ and $\operatorname{sex}(F=6.79, \mathrm{p}<0.01, \mathrm{df}=1)$ had an impact on reported total job satisfaction. Women were more satisfied than men, and those between the ages of 35 and 44 were less satisfied than those younger than 35 or aged 45 or over. Specifically, women were more satisfied with their hours of work $(p<0 \cdot 01)$, recognition $(\mathrm{p}<0.001)$, and freedom to choose methods of working $(\mathrm{p}<0.001)$. Nevertheless, overall, general practitioners felt significantly more dissatisfied with the job than they were in November $1987(t=18 \cdot 4, \mathrm{p}<0.001)$.

TABLE IV-Mean (SE) scores on Warr, Cook, and Wall job satisfaction scale in November 1987 and August 1990 (scores range from 1 to 7 , high score $=$ high satisfaction)

\begin{tabular}{|c|c|c|c|}
\hline Dimensions & $\begin{array}{l}\text { November } 1987^{+} \\
\quad(n=1768)\end{array}$ & $\begin{array}{l}\text { August } 1990 \\
(\mathbf{n}=917)\end{array}$ & $t$ Value $^{\star}$ \\
\hline $\begin{array}{l}\text { Amount of responsibility you } \\
\text { are given }\end{array}$ & $5 \cdot 68(0.02)$ & $4.80(0.05)$ & $17 \cdot 1$ \\
\hline Amount of variety in your job & $5 \cdot 38(0.03)$ & $4.58(0.05)$ & $15 \cdot 0$ \\
\hline $\begin{array}{l}\text { Your colleagues and fellow } \\
\text { workers }\end{array}$ & $5 \cdot 24(0.03)$ & $5 \cdot 31(0 \cdot 04)$ & $1 \cdot 4$ \\
\hline Physical working conditions & $5.11(0.03)$ & $4.44(0.05)$ & $11 \cdot 9$ \\
\hline $\begin{array}{l}\text { Your opportunity to use your } \\
\text { abilities }\end{array}$ & $5.04(0.03)$ & $5 \cdot 44(0 \cdot 04)$ & $7 \cdot 2$ \\
\hline $\begin{array}{l}\text { Taking everything into } \\
\text { consideration, how do you } \\
\text { feel about your job }\end{array}$ & $5 \cdot 23(0.03)$ & $4 \cdot 26(0.06)$ & $18 \cdot 4$ \\
\hline $\begin{array}{l}\text { Freedom to choose your own } \\
\text { method of working }\end{array}$ & $5 \cdot 40(0 \cdot 03)$ & $4 \cdot 77(0.05)$ & $11 \cdot 0$ \\
\hline $\begin{array}{l}\text { Recognition you get for good } \\
\text { work }\end{array}$ & $4 \cdot 76(0 \cdot 03)$ & $3.50(0.05)$ & $23 \cdot 6$ \\
\hline Your rate of pay & $4 \cdot 77(0.04)$ & $5 \cdot 28(0.04)$ & 6.5 \\
\hline Your hours of work & $4.25(0.04)$ & $4.69(0.05)$ & $6 \cdot 3$ \\
\hline
\end{tabular}

^All values significant $\mathrm{p}<0 \cdot 001$.

\section{Discussion}

Our results show a fall in satisfaction and increase in anxiety and depression in 1990 compared with 1987 Male general practitioners, in fact, had worse anxiety and depression than the patients that they treat Women experienced less anxiety and depression, although levels had deteriorated between 1987 and 1990. This significant increase in depression is important, especially as the age profile in the 1990 survey was younger than in 1987 and depression tends to increase with age. ${ }^{16}$ As observed in 1987 , levels of somatic anxiety remained significantly lower than in the general population, although these had significantly increased among both men and women general practitioners.

The consequences of the fall in mental health in terms of patient care and ultimate outcomes for the general practitioners are not known. Myerson's study suggests that three quarters of general practitioners continued working when they felt ill or exhausted. ${ }^{6}$ And doctors are also likely to deny depression and psychotic illness and are often reluctant and uncooperative patients. ${ }^{18}$ These problems are likely to be masked by alcohol or drug dependence, or both. Statistics show that general practitioners are particularly prone to alcoholism, drug dependence, and depression (R E Steel, spring meeting of Royal College of General Practitioners, Harrogate, 1990), ${ }^{19}$ and suicide rates among doctors in the United Kingdom are still a major cause of concern.

\section{EFFECT OF DETERIORATING MENTAL HEALTH}

The relation between self reported anxiety, depression, and dissatisfaction and risk of serious ill health is complex; the links between stress and job dissatisfaction are less clear among professionals in high status occupations. However, French and Caplan have shown that work overload, role ambiguity, and role conflict contribute to several indicators of physiological and psychological strain, including job dissatisfaction. ${ }^{20}$ Thus it is not surprising that general practitioners also reported lower levels of job satisfaction than they did at the end of 1987.

Previous research has suggested that job dissatisfaction among general practitioners has serious implications in terms of patient care. ${ }^{21}$ Satisfaction and feeling at ease were associated with openness to patients and more attention to the psychosocial aspect of complaints, whereas frustration and lack of time were related to increased prescribing and a decrease in the tendency to provide explanations to patients. ${ }^{21}$ In addition, intrinsic job dissatisfaction may be associated with increased risk of coronary heart disease. ${ }^{22}$

\section{EXPLANATION OF RESULTS}

Although general practitioners reported higher levels of stress in 1990 than in 1987, this may not be wholly related to the introduction of the new contracts. Doctors had worked in a climate of considerable change, upheaval, and uncertainty for a long time before the contract was introduced. In fact, some return to normality might have been expected in the 1990 survey.

All the data collected in this study were self reported, and respondents could have identified the aims of the survey and attempted to provide socially desirable responses. Although some may have acted in this manner, certain factors will have minimised this effect. Firstly, both data sets were large, and we were able to check the validity of certain variables with repeat measures, the results of which were consistent with the survey's results (details available from authors). Secondly, the 1990 survey was not anonymous and so the respondents knew that follow up was possible. Hopefully, the use of an independent research body to conduct the survey ensured that replies were reasonably honest and that confidentiality was assured. Thirdly, if the results were distorted we would have expected to see global rather than selective distortion, and this was not the case.

General practitioners might now be more willing to report feelings of anxiety, depression, and dissatisfaction as attitudes towards psychosomatic illness have changed, especially among the younger members of the profession and women practitioners. Stress has become a respectable topic for discussion within the profession; it has become more acceptable to admit to strain and pressure and to discuss ability to cope with the job.

\section{Conclusions}

Changes will continue in the life of general practitioners. For example, as practice based on personal care moves more towards a system of polyclincs ${ }^{23}$ and fundholding, the need for effective team working and the careful definition of the role of the general practitioner in health care will be even more important. Also, as many more women are now in full time paid work traditional spouse-partner roles are changing. This results in changes in family support networks; 
overspill of work into home life; and role conflict. ${ }^{1}$ Indeed, the dynamics of a practice will alter as more women enter the profession as women are more likely to work part time than men. ${ }^{+}$Thus it is important that the impact of change is carefully monitored to avoid adverse impact on this profession. Ideally, a survey using both subjective and objective data is needed to determine the ongoing nature of these findings.

1 Karasek RA Jr. Job demands, job decision latitude and mental strain: implications for job re-design. Administrative Science Quartely 1979;24:285308.

2 Porter AMD, Howie JGR, Levinson A. Measurement of stress as it affects the work of the general practitioner. Family Pract 1985;2:136-46.

3 Morrell DC, Evans ME, Roland MO. The "five minute" consultation: effect of time constraint on clinical content and patient satisfaction. BMJ 1986;292: 870-3.

+ Cooper CL, Faragher B, Rout U. Mental health, job satisfaction, and job stress among general practitioners. BMF 1989;298:366-70.

Howie JGR, Porter AMD, Forbes JF. Quality and the use of time in general practice: widening the discussion. BMF 1989;298:1008-10

Myerson S. Under stress? Practitioner 1990;234:973-6.

7 Macpherson G. BMA sends the GP's' contract out for consultation. BMJ 1989;298:1406-7.

Morrell $D$. The new general practitioner contract: Is there an alternative? $B M J$ $1989 \cdot 298: 1005-7$.

9 Smith T. BMA rejects NHS review. BMf 1989;298:1405-6.
10 Scheiber SC. Stress in physicians. In: Payne R, Firth-Cozens J, eds. Stress in health professionals. Chichester: John Wiley, 1987:23-44.

11 Porter AMD, Howie JGR, Levinson A. Stress and the general practitioner. In: Pavne R, Firth-Cozens J, eds. Stress in health professionals. Chichester: John Wiley, 1987:45-70

12 Marsh G, Kaim Caudle P. Team care in general practice. London: Croom Helm, 1976

13 Van Sell M, Brief AP, Schuler RS. Role conflict and role ambiguity: integration of the literature and directions for future research. Human Relations 1981:34:43-71.

14 Selye H. Stress without distress. Philadelphia: Lippincott, 1979

15 Sutherland VJ, Cooper CL. Understanding stress: a psychological perspective for health professionals. London: Chapman and Hall, 1990:165-224

16 Crown S, Crisp AH. Manual of the Crown-Crisp experiential index. London: Hodder and Stoughton, 1979

17 Warr P, Cook J, Wall T. Scales for the measurement of some work attitudes and aspects of psychological well being. Fournal of Occupational Psycholog 1979;52:129-48.

18 a'Brook M. Psychosis and depression. Practitioner 1990;234:992-3.

19 Lloyd G. Alcoholic doctors can recover. BMF 1990;300:728-30.

20 French JRP, Caplan RD. Organisational stress and individual strain. In Marrow AJ, ed. The failure of success. New York: Amacon, 1973:30-66.

21 Grol R, Mokkink H, Smits A, Van Eijk J, Beck M, Mesker P, et al Work satisfaction of general practitioners and the quality of patient care. Fam Pract 1985;2:128-35.

22 Sales SM, House J. Job dissatisfaction as a possible risk factor in coronary hear disease. 7 Chronic Dis 1971:23:861-73.

23 Keeley D. Personal care or the polyclinic? BMJ 1991;302:1514-6.
This is the fourth in a series of articles dealing with aspects of managing change in general practice.

The Cairntoul Practice, Glasgow G14 0XT Mairi G B Scott, general practitioner

MSD Foundation, London E14 9WA

Marshall Marinker, director

BMf 1992;304: $1548-50$

\title{
Managing Change in Primary Care
}

\section{Imposed change in general practice}

\author{
Mairi G B Scott, Marshall Marinker
}

In the summer of 1989 the government published its intentions for the reform of the NHS, and for a new contract with general practitioners. Both the reforms and the contract were immediately subject to a host of detailed criticisms about content. But behind these criticisms there lay another - that the government was imposing the changes.

All change gives rise to two recriprocal anxieties. Abandoning established habits and arrangements and embracing new ones produce the anxiety of loss and the anxiety of the unfamiliar. In this article we are concerned not with the content of change but with its processes. Although we take as our starting point the concerns occasioned by the reforms of the NHS in the past three years, we do so in order to highlight the problems which can arise within each general practice when change is envisaged. These problems are magnified when there is a sense of imposition, of being the victim and not the agent of change.

This sense of imposition seems to relate to four factors: firstly, the degree to which the reasons for change seem to be arbitrary; secondly, the strength of the evidence of the need for change; thirdly, the degree to which the changes are expressed in terms of desired behaviours as opposed to desired outcomes; and, fourthly, the choice of strategies used to effect the change. We examine these factors in detail below.

\section{Reasons for change}

For the most part in general practice the reasons for change seem to be accidental. That is to say they seem to be a part of what may be described as the natural development of a practice. Even when they take place suddenly or unexpectedly they are accepted because the reasons are perceived to be inevitable - the product of human vagaries. There may be shifts in the local population, perhaps the proportion of elderly people has increased over the years; patterns of morbidity may change, sometimes abruptly; there may be staff related problems - partners quarrel, become ill, or resign; the practice may be invited to start vocational training; and

\section{Points to note}

- Change necessitated by circumstances is acceptable in general practice

- Change willed and enforced by others is considered arbitrary

- Often evidence is not available for required change

- Change based on fashion is less acceptable than that based on sound evidence

- Imposed change is more acceptable if it is expressed in terms of outcome rather than detailed behaviour

- The positive way to deal with imposed change is to create a sense of ownership of the change within the practice

so on. Such reasons for change may be burdensome but they will be perceived as accidental. They will certainly pose difficult problems but they will not be seen as having been arbitrarily imposed.

When change is perceived as having been willed by others rather than occasioned by need there is a sense of arbitrariness. The new contract, again, is the most obvious recent example. It was the sense that activities were willed as a matter of policy, politically decided and enforced by a monopolistic employer or commissioner, that caused the sense of helplessness and hopelessness.

It is not only governments that can engender these negative feelings. They can and often do arise within partnerships and group practices. A precedent partner arbitrarily decides to change his half day, or blocks the use of a deputising service, or persistently frustrates the wish of the others to employ additional staff. Change seems to be arbitrary when the initiator is strong and the evidence of need for change is weak.

\section{Evidence of the need for change}

It would be comforting if all the changes required in general practice were based on reliable evidence from 